\title{
SCIENTIFIC PREDICTION OF THE BALANCED ENERGY SAVING DEVELOPMENT STRATEGY OF THE CONSTRUCTION PROJECTS
}

\author{
Volodymyr Tkachenko, Maryna Klymchuk, and Iryna Ivakhnenko
}

\begin{abstract}
The article explores the process of syncretisation of the concepts of "Green Lease", "Surveying" and "Balanced Scorecard" in the formation of strategy of energy saving development of construction projects. As a result of the conducted analysis of the systems, it was proposed to incorporate the category "energy saving development" to scientific terminology from the perspective of increasing energy efficiency and energy saving of the construction projects, defined as scientific categorical status of this concept. Within the framework of four interconnected main projects of the Balanced Scorecard, a basic model of the energy saving development system of construction projects is formed, taking into account the purpose, the stages, and schemes of implementation. Conceptual and integrative approaches have been implemented in the energy saving development system of construction projects based on the symbiosis of modern concepts of "Green leasing" and "Surveying", which will provide the opportunity to use the latest effective practices in the construction of energy efficient buildings. The strategic map for implementation of energy saving development for LLC "KAN Development" was developed, where the proposals of the implementation of an effective strategy on the energy saving platform with the regard to innovative management and energy efficient technologies were presented within four projections of "Balanced Scorecard" (finance, customers, business processes, personnel).
\end{abstract}

Keywords: Balanced Scorecard, Green Lease, Surveying, energy saving, strategy, management, enterprise, development

JEL Classification: D2, M12, 013, P18 


\section{Author(s):}

\section{Volodymyr Tkachenko}

Kyiv National University of Construction and Architecture, 31 Povitroflotsky Avenue, Kyiv, Ukraine, 03680

E-mail: vladymyr8888@gmail.com

https://orcid.org/0000-0003-2114-7194

\section{Maryna Klymchuk}

Kyiv National University of Construction and Architecture, 31 Povitroflotsky Avenue, Kyiv, Ukraine, 03680

E-mail: klimarinchuk@gmail.com

https://orcid.org/0000-0002-1024-4784

\section{Iryna Ivakhnenko}

Kyiv National University of Construction and Architecture, 31 Povitroflotsky Avenue, Kyiv, Ukraine, 03680

E-mail: ivakhnenkoirina@ukr.net

https://orcid.org/0000-0001-7166-1023

Citation: Tkachenko, V., Klymchuk, M., \& Ivakhnenko, I. (2019). Scientific prediction of the balanced energy saving development strategy of the construction projects. Virtual Economics, 2(2), 70-84. https://doi.org/10.34021/ve.2019.02.02(5)

Received: December 18, 2018. Revised: January 16, 2019. Accepted: March 29, 2019.

(C) Author(s) 2019. Licensed under the Creative Commons License - Attribution 4.0 International (CC BY 4.0) 


\section{Introduction}

One of the strategic imperatives of country's development is to improve the energy efficiency of the real economy, which is caused by high levels of energy intensity, the needs of society in a significant amount of energy and modernization of the national economy, with the need to improve the competitiveness of the enterprises of the construction complex.

The concentration of interest in energy efficiency, both from the position of scarcity of fuel and energy resources, and of competitiveness of national industries, has led to the fact that this vector is considered as an indicator that mediates economic and social development and energy independence in developed countries.

The priority is to solve the problem of realization of the potential of energy saving construction resource, where, according to experts estimate, it is $55 \%$. There is a need in the application of new energy saving efficiency in terms of the dynamism of the external business environment, growth of the market risks of dissonance in the construction industry (Kulikov \& Klymchuk, 2017).

The current state of the economic development of the country determines the search for constructive solutions in the field of energy saving based on advanced concepts, such as "Environmental economics", "Passive house", "Triple Zero", "NZEB", "Surveying", "Green Lease", which can be solved on the basis of development of the energy saving development system (Chernyshev et al., 2018).

There is a need in the interaction of the basic structural components (economic, social, environmental) of modern environmental development of society in the context of the implementation of energy efficiency measures, which can be solved through the development of energy saving development system (Chernyshev et al., 2018).

Researchers investigate the development implementation problem in modern forms of industrial-economic relations in their writings (Barbier, 1989; Baronin, 2013; Fesun, 2014; Mulhearn \& Vane, 2016; Peiser \& Frej, 2003). Some researchers interpret the essence of development as a construction process, realtor activity, management of commercial real estate (Fesun, 2014). However, in our opinion, such an approach only fragmentarily highlights the specifics of development.

M. Ashouria, F. Haghighat, B.C.M. Fung, A. Lazrak, and H. Yoshino (2018) proposed a new methodology for monitoring energy consumption of the building.

This study proposes a new methodology for monitoring the energy consumption in building end-use loads to build an advisory system. The built system alerts occupants to take certain measures (prioritized recommendations) to reduce energy consumption of end-use loads. The quantification of potential savings is also provided upon following measures. The proposed methodology is also capable of evaluating the energy savings performed by the 
occupants. The system works based on the analysis of historical data generated by occupants using data mining techniques to output highly feasible recommendations. For demonstration purposes, the methodology was tested on the real dataset of a building in Japan. The dataset includes detailed energy consumption of end-use loads, categorized as hot water supply, lighting, kitchen, refrigerator, entertainment and information, housework and sanitary, and others. The results suggest that the developed models are accurate, and that it is possible to save up to $21 \%$ of total energy consumption by only changing occupants' energy use habits (Ashouria et al., 2018).

Energy consumption for a full cycle of operation of buildings in Ukraine is in average more than $300 \mathrm{kWh} / \mathrm{m}^{2}$ per year of the heated area. In this case, emission of about $35 \%$ of all greenhouse gases is created (Kulikov \& Klymchuk, 2017). The above needs to address the issue of environmental protection, healthy lifestyle and an updated study of the problem of implementation of energy saving development for the sustainable development of the national economy. The construction of passive houses is one of the solution vectors of the problem of optimizing the structure of energy consumption, that will lead to the feasibility of using renewable energy sources and modern technical and economic solutions in the context of energy saving in construction.

It is expedient to implement the main directions of energy efficient construction taking into account the provisions of energy saving development. Statistics of foreign and domestic developers testify to the reality of obtaining the following economic effects from the implementation of the development system (in comparison with the traditional forms of organization of the investment process):

- reduction of the duration of the stages of development and implementation of the project by $7-15 \%$, including the stage of the construction work - by $10-25 \%$;

- reduction of the complexity of the stage of project implementation by 5-15\%;

- reduction of the construction by $10-20 \%$;

- reduction of the operating costs by $15-25 \%$;

- reduction of the expenses for the entire project by 5-15\% (Fesun, 2014; Peiser \& Frej, 2003).

Therefore, the presented data substantiate the feasibility of the development of the concept of balanced energy saving development as a basis for the formation of the system management of construction projects on the energy saving platform.

\section{Literature review}

A modern approach to the formation of the system of the development of construction projects based on the implementation of the neoclassical paradigm focuses on maximizing profits and liquidity. In terms of innovative development of the economy on the energy saving platform, there is a need to develop a comprehensive methodology for energy saving development and appropriate tools for its implementation. This methodology will provide the opportunity to transform the information-analytical and organizational and economic 
structure of the construction project to find solutions to the basic problems of its development that promote sustainable economic growth in the present and future periods; as a toolkit, it is proposed to use the concept of "Balanced Scorecard".

The concept of "development" has two interrelated values. The first, development is the modernization of the real estate, which provides its conversion into another new object, which has a higher market value than the value of the original object. Thus, development is a process of the development of the estate.

The second, development is a professional activity of the organization (management) processes in construction. This is a special type of entrepreneurial activity in market conditions and manifestation of business activity on the market. The role of the developer has some specifics on all stages of the investment - construction project, and differs from the role of other participants (Peiser \& Frej, 2003; Fesun, 2014).

We agree with the above mentioned authors' proposals which represent the essence of development through the lens of two interrelated values, but we propose to supplement this characterization based on the conceptual integration approach that provides the symbiosis of the two previous characteristics, taking into account modern concepts of "Green leasing" and "Surveying" which will provide the opportunity to use the latest effective development practices in construction.

One of the trends of the development of the world economy in the field of commercial management is active dissemination of the conception of "Surveying" in science and practice. Requirement of the effective adjusting of the real estate market development as a key sector of the national economy of any country has determined the origin of independent professional activities in the form of Surveying. The study of international experience shows that the use of a professional approach to the property management provides the opportunity to significantly increase the level of its effectiveness in the interests of all stakeholders (owners, tenants, government and society in general). Such a conceptual approach regarding management of property is called "Surveying" (Baronin, 2013). The conception of "Surveying" can be interpreted today as totality of legal, technical, economic and managerial expertise of the real estate, which provides a maximum effect of its use. "Green Lease" is one of the tools that formalizes duties among leaseholders and tenants with energy efficiency measures in the building (Brooks, 2008).

That is why, the solution is proposed to synchronize the concepts of "Surveying" and "Green Lease" to solve the problems of elaborating the methodology of balanced energy saving development, which will enable the fruitful cooperation between the owners of commercial real estate and tenants in the context of implementing energy efficient measures in the building. The economic aspect of the development is implemented to increase the value of the property as a result of modernization. Increase as a result of the modernization of the value of the object provides the appearance of real estate with new consumer qualities, which make it more attractive on the market. Legal aspects of the development are 
associated with the legal registration of the performed changes, the emergence of a qualitatively new property, which has a higher value (Peiser \& Frej, 2003).

Development means the property development-construction, engineering and other operations on real estate, it leads to a qualitative transformation, because development is the process of project implementation (Chernyshev et al., 2018).

From the perspective of attracting additional financial resources into the activity of the production-economic system, Feson A.S. defined the development as a form of organization of an investment project in the field of real estate, and directly the development project is the investment project, which is a set of interrelated activities with available resources to create new long-term assets for further return on investment and income (Fesun, 2014).

\section{Methods}

The theoretical and empirical basis of the research were the methods of scientific cognition, general scientific principles, achievements in the sphere of energy saving of enterprises. The conceptual-integration approach provides symbiosis of modern concepts of "Green Leasing", "Surveying" and "Balanced Scorecard" (Baronin, 2013; Brooks, 2008; Kaplan \& Norton 1996).

The suggestion is to implement into the research the definition of "energy saving development" due to the significant energy intensity of the national economy, the growing demand for energy in the enterprises, the need for modernization of housing and communal services, and the availability of foreign concepts that offer a number of energy efficiency measures that are appropriate to be implemented at the development stage of construction in order to increase the level of energy saving of enterprises, social infrastructure. The concept of energy saving development has not yet been defined in science. Obviously, before making managerial decisions, it is necessary to have clear representation of the essential characteristics of this term, because the correct definition helps to understand the choice of strategy to increase energy efficiency at the enterprise level and the country on the whole (Dzwigol \& Dzwigol-Barosz, 2018; Dzwigol et al., 2019; Karpenko et al., 2018; Meneses-Viveros et al., 2018; National Action Plan for Energy Efficiency, 2008; Pajak et al., 2017; Thøgersen, 2018; Zhang et al., 2018).

Energy saving development should not be equated to the economic efficiency of energy consumption. The energy saving does not always turn out to be the most economically effective, since the achievement of high energy efficiency sometimes requires significant investments, the payback of which cannot always be ensured by the energy savings achieved in reasonable time. The significant achievement of energy saving, as a rule, requires investment costs, and saved energy receiving must be commensurate with the relevant investment costs. Further, according to the results of the definitive analysis, the determinants of incorporation of energy saving development into the theoretical and practical areas of construction management were proposed (Table 1). 
Table 1. Determinants of incorporation of energy saving development into the theoretical and practical sphere of management of a construction project

\begin{tabular}{ll}
\hline $\begin{array}{l}\text { Determinant } \\
\text { Comfortable } \\
\text { housing }\end{array}$ & $\begin{array}{l}\text { Characteristic } \\
\text { housing through the introduction of modern technologies }\end{array}$ \\
\hline $\begin{array}{l}\text { Conceptualism of } \\
\text { energy saving } \\
\text { construction }\end{array}$ & $\begin{array}{l}\text { One of the trends of the development of the world economy in the field of } \\
\text { commercial real estate management; there is an active dissemination of the } \\
\text { concepts of "Surveying" and "Green Lease" in the science and practice }\end{array}$ \\
\hline Legal & $\begin{array}{l}\text { The legal basis of passive housing, energy audits and energy certification of } \\
\text { buildings construction }\end{array}$ \\
\hline Ecological & $\begin{array}{l}\text { Investing in the development projects in the construction of energy efficient } \\
\text { housing, which has no negative environmental impact; using modern energy } \\
\text { efficient technology that increases the cost and the prestige of such housing }\end{array}$ \\
\hline Financial and & $\begin{array}{l}\text { Introduction of energy efficient development will reduce energy consumption } \\
\text { of buildings throughout the life cycle, and will provide an opportunity to attract } \\
\text { significant investments through enhancing energy efficiency of the state politics }\end{array}$ \\
\hline
\end{tabular}

Source: own research.

Therefore, we propose that "energy saving development" is a system of implementation of a complex of measures of economic, technical, technological, legal, environmental and social nature aimed at reducing the cost of energy efficiency in the building on the basis of the implementation of energy efficient technologies and management practices, as well as improving organizational and managerial areas, optimization of interaction links within the production chain, optimization of business processes, increase of management efficiency.

Considering the proposals of the implementation of energy saving development in theory and practice of implementation of energy efficiency measures in the construction, we propose forming an effective strategy and its estimation based on Balanced Scorecard.

Balanced system of energy saving development of construction projects provides achievement of goals and long-term sustainable advantages over competitors. System of energy saving development of construction projects from the perspective of principles of equity is very important for the developer because of its promotional efficient use in existing advantages, and creates new potential activities.

The successful implementation of a balanced system of energy saving development of construction projects requires the assessment of:

- the external and internal environments;

- the competition;

- the key success factors;

- the strategic plans and economic indicators of activity;

- the factors that affect the reduction of energy consumption.

If we present the proposed system of balanced energy saving development of construction projects as a method of organization, through which you can monitor the activities of the 
enterprise in the context of management and implementation of energy efficient measures, then there is a need to define indicators, absolute and relative quantities, which will allow the quantitative form of reflection of some kinds of the developer's economic activity on the energy saving platform.

Since the information content of some indicators are limited, and when they are used without taking into account all the relevant economic and analytical information they may be misinterpreted, it is advisable to offer an informative system in order to maintain the principle of complexity of energy saving development of construction projects. Within the framework of the balanced system of indicators of energy saving development of construction projects, the emphasis should be on using the data on the assessment of changes in current and potential performance. The performance indicator reflects quantitative characteristics, that is, the ratio of the costing result.

Balanced system of energy saving development of the construction projects of external and internal environment examines key indicators of effectiveness, since this assessment system helps the organization identify ways of achieving strategic goals. Their use allows developer to assess the status of implementation of the strategy.

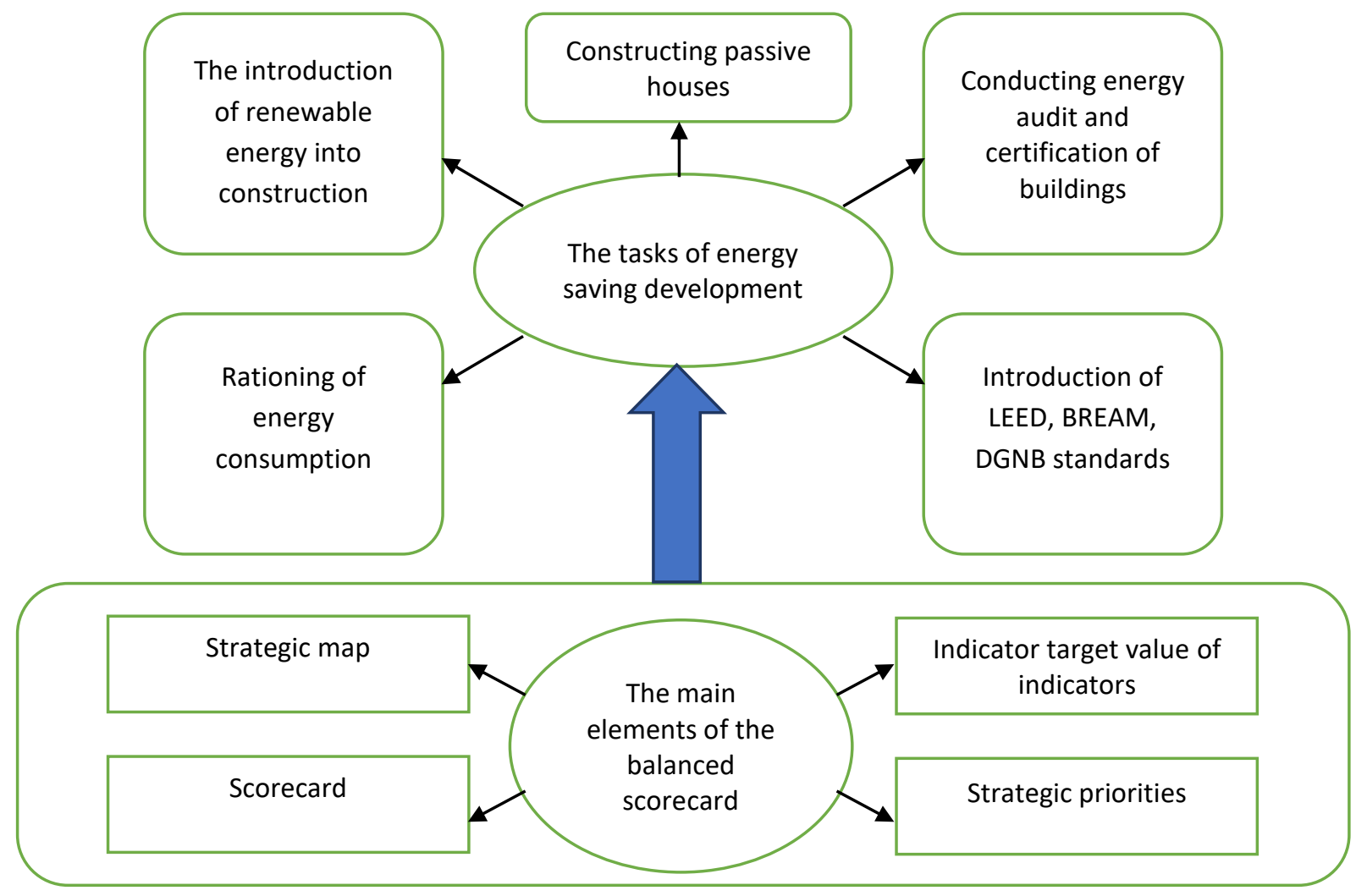

Figure 1. Conceptually balanced saving development

Source: own research on the basis of Balanced Scorecard (Kaplan \& Norton, 1996). 
The concept of balanced energy saving construction projects should be based on balanced scorecard and include basic concepts regarding the implementation of measures of energy saving in construction Fig. 1.

A balanced system of energy saving development of the construction projects is an integrated technology of coordination of energy saving management project, created to maintain a system of indicators needed to increase energy efficiency, profitability and quality of customer service, taking into account the relationship between various aspects of the development strategy of the developer.

The aim of the balanced energy saving development of construction project system is the coordination on basis of relevant information of causal relationship between the cost system and the drivers of effective results. We propose to consider energy saving development of construction projects on the basis of Balanced Scorecard in the form of a structuredanalytical scheme consisting of five stages Fig. 2.

Stage 1. Initiation of energy saving development of construction project

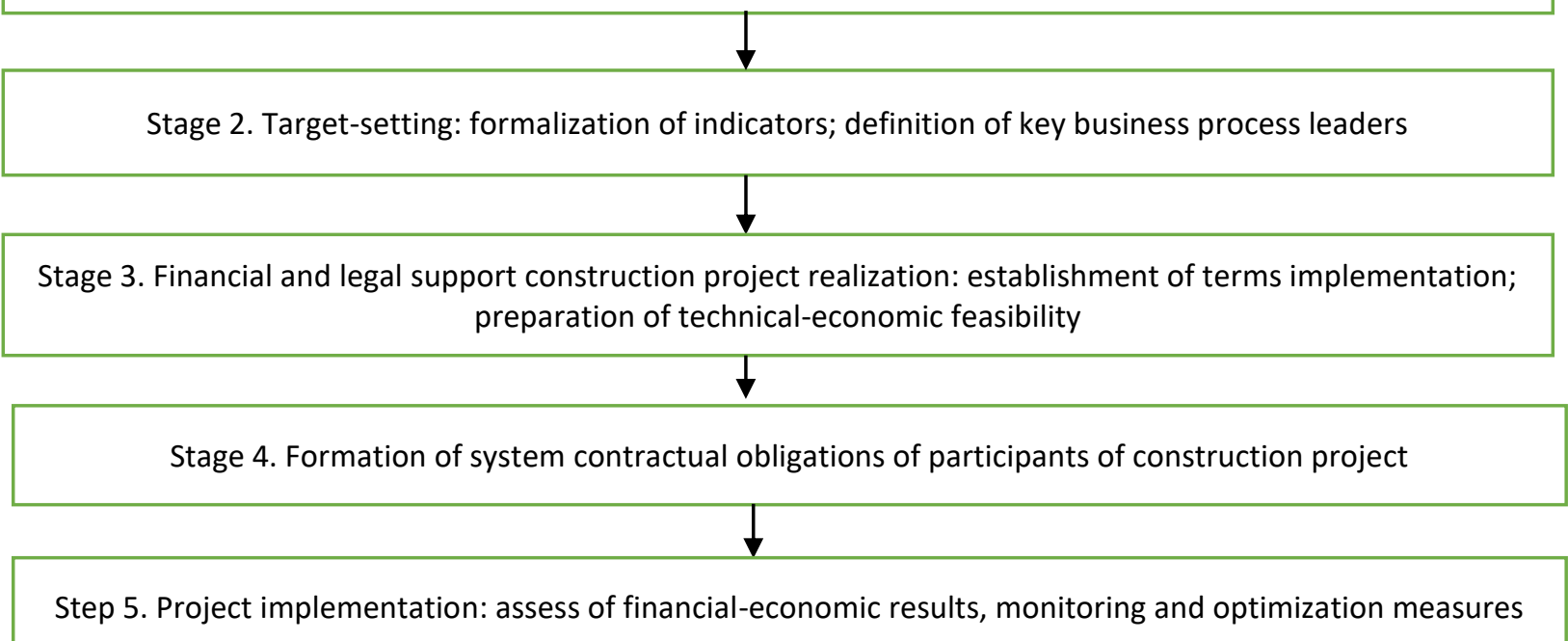

Figure 2. Stages of implementation of balanced energy saving development of construction projects

Source: own research.

According to the authors, the key business processes of the system of balanced energy saving development of construction projects should be implemented according to the scheme Fig. 3.

Balanced system of indicators (Balanced Scorecard, BSC), offered by scientists R. Kaplan and D. Norton provides an opportunity to develop an effective strategy for formation energy saving development projects within four interconnected main projections (Kaplan \& Norton, 1996). The four indicators of Balanced Scorecard, with the determinants of energy saving, are presented in Fig.4. 


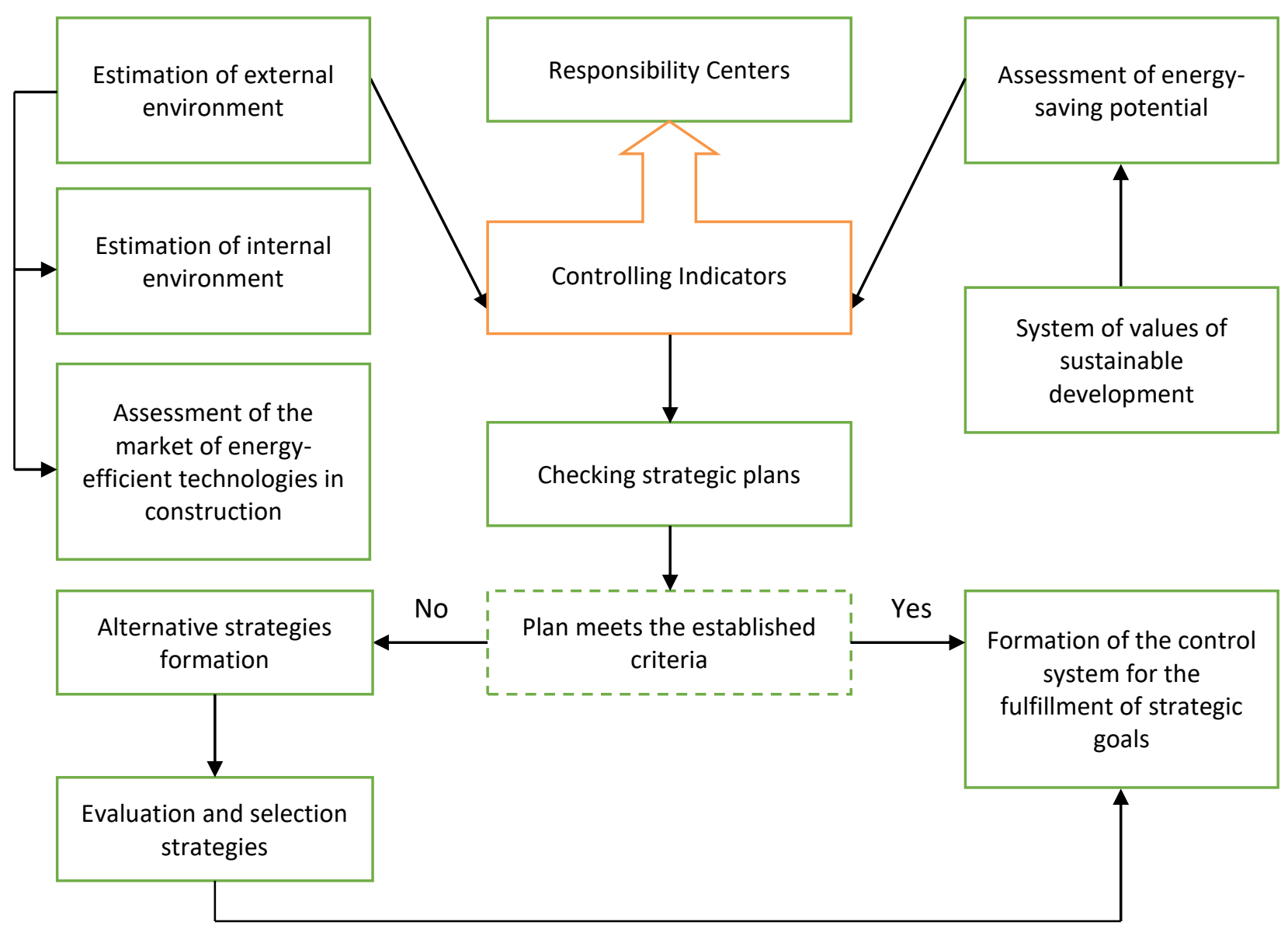

Figure 3. The realization scheme of the system of balanced energy saving development of the construction project Source: own research.

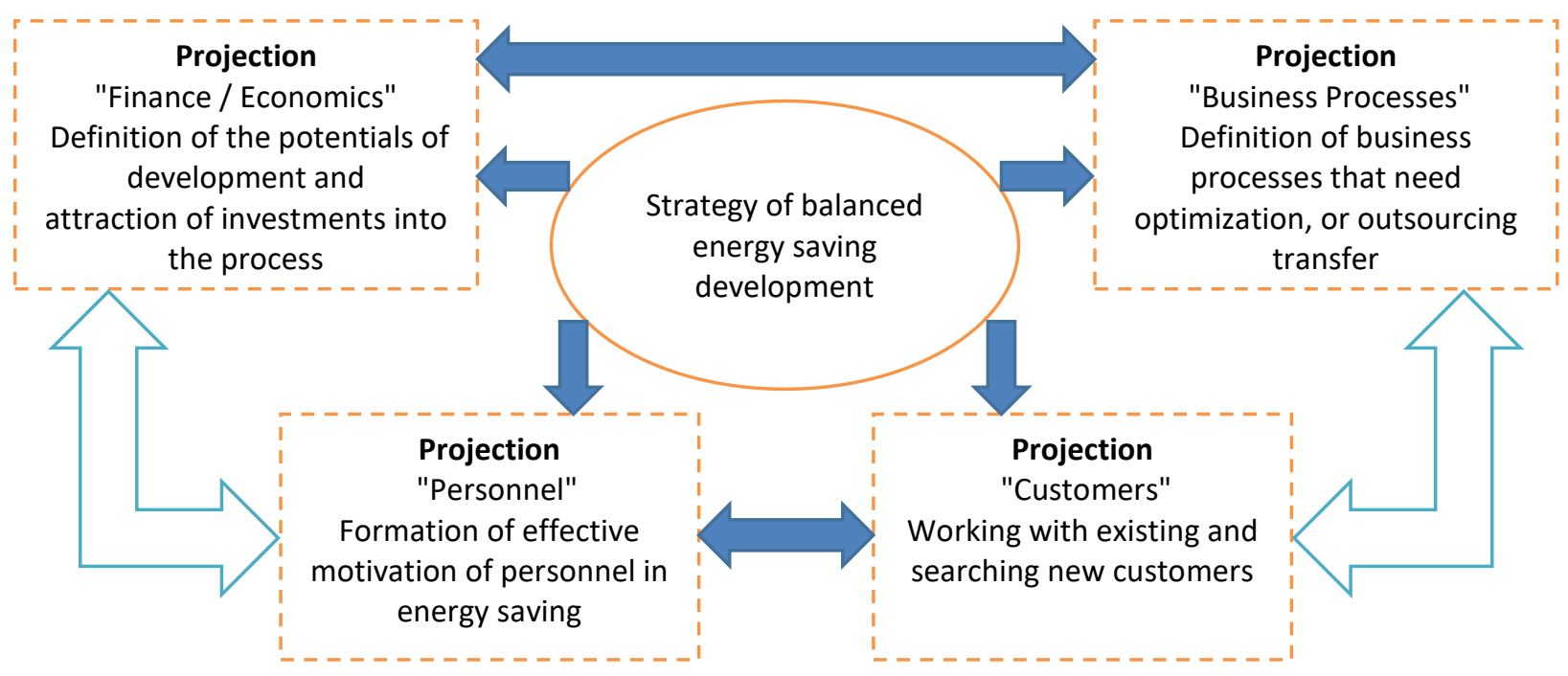

Figure 4. The basic model of the system of balanced energy saving development of the construction project

Source: own research. 
The four components of balanced system of indicators are interconnected and should promote the implementation to a unique strategy of balanced energy saving development of construction projects. Though, the Balanced Scorecard does not reach all aspects of the developer's activity, but concerns only those aspects that will be used to achieve strategic energy saving goals.

The orientation of the system for balanced system of energy saving development of construction projects for long term, require taking into account the factors of time and risks, analysis of the industrial and general development potential of the developer, the integration of all management functions.

Accordingly, the tools of the proposed system are:

- analysis of the strengths and weaknesses of the developer, regarding opportunities and threats;

- benchmarking, market analysis;

- cost assessment at all stages of the life cycle of a construction project;

- functional - cost analysis;

- analysis of impact of the formation of energy saving development on the ecological state of the region;

- portfolio analysis;

- potential and competition analysis;

- balanced system of indicators.

\section{Results}

On the foundation of conceptual integration approach that implies the symbiosis of the modern concepts of "Green leasing" and "Surveying", we will consider the application of the tools of a balanced system of energy saving development of construction projects of KAN Development LLC management. For the exploring developer, it is advisable to choose a strategy of reducing energy consumption, with reducing that in the main production. At the same time, the amount of production will continue to be sufficient on effective management level.

The development of the strategy requires a definition of the main goal. In "KAN Development" LTD, the main targets are defined as optimization of expenses in building constructions, realization of energy saving projects and energy efficiency in construction. After determination of primary strategic purpose of the developer, aims and tasks are formed, in relation to their implementation within the framework of four projections of a balanced system of indicators. In general, the process is presented as a strategic map of the explored developer, the instrument that will enable the symbiosis of goals and tasks at different stages of balanced energy saving development. Strategic map of the implementation of the energy saving development project of KAN Development Ltd presented in Fig. 5. 
The degree of execution of each strategic task must be measured by a certain set of indicators expressed in absolute or relative numerical values. Within the framework of a balanced system, they have key performance indicators.

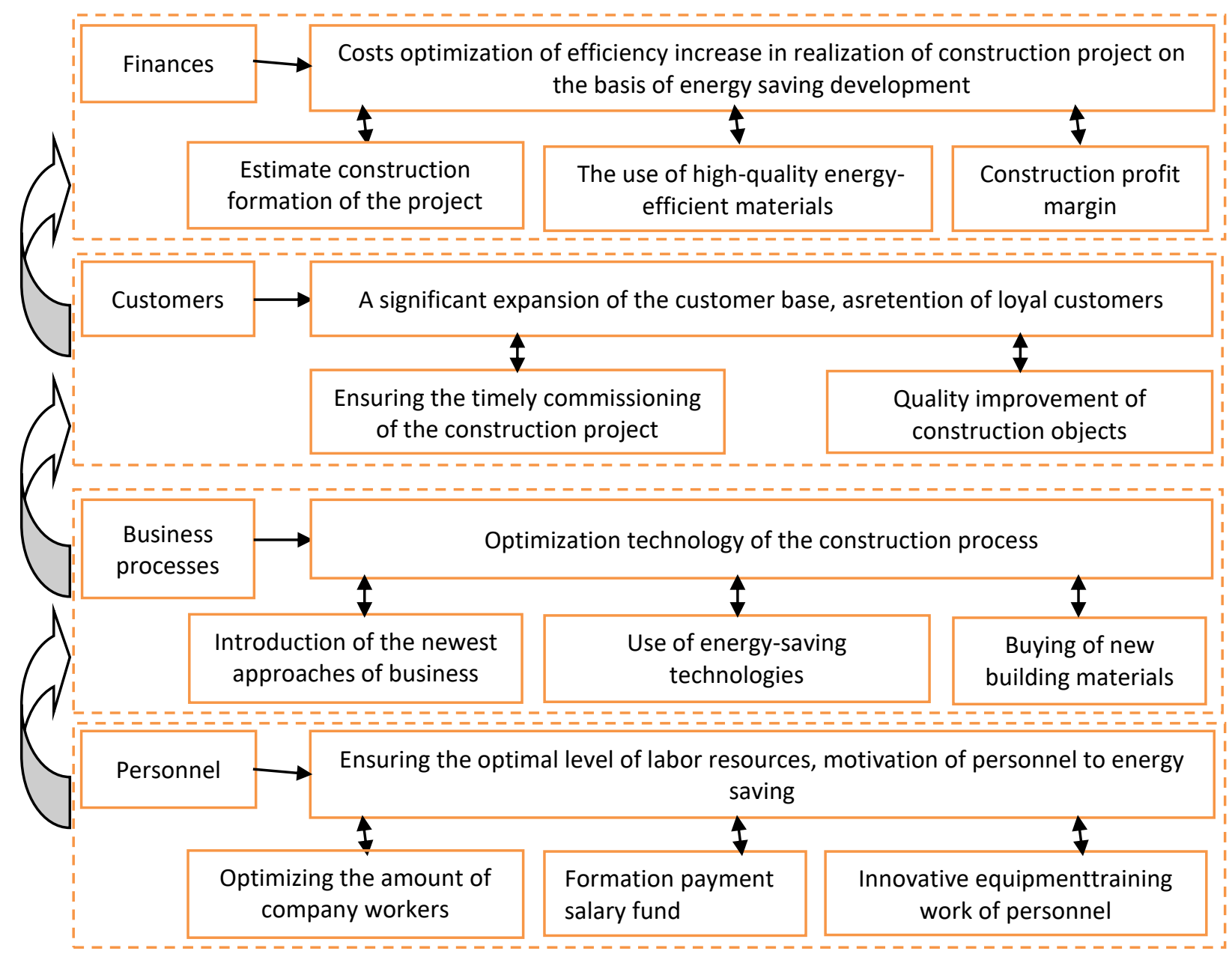

Figure 5. Strategic card for implementing energy saving development of LLC KAN Development

Source: own research.

The achievement of the financial objectives of the developer is verified by comparing the planned and actual performance indicators in the chosen direction. Based on the study, conclusions are drawn about the need to reduce (increase) a specific indicator in the dynamics.

\section{Conclusions}

In today's conditions of development of the real estate sector of the economy, in particular construction, there is a problem of ensuring their energy efficiency, energy independence and energy security that can be realized through the introduction of energy saving development of construction projects. Based on the results of the systematic analysis carried 
out, the proposal on incorporation the category of "energy saving development" into the scientific terminology in the context of increasing the level of energy efficiency and energy saving of construction projects was substantiated, and the scientific and categorical status of this concept was determined.

In order to form an effective strategy for energy saving development of construction projects, proposals for the syncretisation of the concepts of "Green Lease", "Surveying", "Balanced Scorecard" in the process of its implementation are provided. Within the framework of four interconnected key projections of the Balanced Scorecard, a basic model of the balanced system of energy saving development of a construction project has been formed taking into account the purpose, stages, implementation schemes.

The conceptually-integration approaches are incorporated into the system of energy saving development that implies the symbiosis of the modern concepts of "Green leasing" and "Surveying", which will provide the opportunity to use the newest effective practices in the construction of energy efficient buildings.

A strategic map of the implementation of sustainable energy saving development for KAN Development LLC was developed, where within the framework of four Balanced Scorecard projections (finance, clients, business processes, personnel), proposals for implementation of effective strategy of energy saving platform are presented, taking into account innovative management and energy efficient technologies.

Prospects for further research are the development of an economic-mathematical model based on a strategic map of energy saving development, which will allow to determine the structure of the system of balanced indicators by the categories of production costs and to offer methods for their optimization.

\section{References}

Ashouria, M., Haghighat, F., Fung, B.C.M. Lazrak, A., \& Yoshino, H. (2018). Development of building energy saving advisory: A data mining approach. Energy and Buildings, 172, 139-151. https://doi.org/10.1016/j.enbuild.2018.04.052

Barbier, E. B. (1989) Economics, natural resource scarcity and development: conventional and alternative views. London: Earthscan Publishers. https://doi.org/10.1002/jid.3380020410

Baronin, S. A. (Ed.). (2013). Serveying $v$ stoitelstve: opyt I perspektivy razvitiya [Surviving in construction: experience and prospects of development]. Penza, Russia: PGUAS. (in Russian)

Brooks, S. M. (2008) Green Leases and Green Buildings. Retrieved from https://cdn.ymaws.com/www.realpac.ca/resource/resmgr/leases/greenleasesandbuildings16ma y.pdf 
Chernyshev, D., Ivakhnenko, I. \& Klymchuk, M. (2018) The organization of biosphere compatibility construction : justification of the predictors of building development and the implementation prospects. International Journal of Engineering \& Technology, 7(3.2), 584-586. http://doi.org/10.14419/ijet.v7i3.2.14594

Dzwigoł, H., Dzwigoł-Barosz, M., Zhyvko, Z., Miskiewicz, R., \& Pushak, H. (2019). Evaluation of the energy security as a component of national security of the country. Journal of Security and Sustainability Issues, 8(3), 307-317. http://doi.org/10.9770/jssi.2019.8.3(2)

Dzwigol, H., \& Dzwigol-Barosz, M. (2018). Scientific research methodology in management sciences. Financial and Credit Activity: Problems of Theory and Practice, 2(25), 424437. https://doi.org/10.18371/fcaptp.v2i25.136508

Kaplan, R. S., \& Norton, D. P. (1996). Linking the Balanced Scorecard to Strategy. California Management Review, 39(1), 53-79. http://doi.org/10.2307/41165876

Karpenko, L., Serbov, M., Kwilinski, A., Makedon, V., \& Drobyazko, S. (2018). Methodological platform of the control mechanism with the energy saving technologies. Academy of Strategic Management Journal, 17(5), 1939-6104-17-5-271: 1-7. Retrieved from https://www.abacademies.org/articles/Methodological-platform-of-the-control-mechanism1939-6104-17-5-271.pdf

Kulikov, P. M. \& Klymchuk, M. M. (2017). Upravlinnia enerhozberezhenniam na budivelnykh pidpryiemstvakh: teoriia, metodolohiia, praktyka [Management of energy saving in construction enterprises: theory, methodology, practice]. Ivano-Frankivsk: Foliant. (in Ukrainian).

Fesun, A. S. (2014). Tsilove fonduvannya yak alternatyvnyi instrumentariy investuvannya developerskich proyektiv [Target Funding as an Alternative Instrument of Investing into Development Projects]. Business Inform, 5, $106-110$ (in Ukrainian).

Mulhearn, C., \& Vane, H.R. (2016). Economics for Business. Third Edition. UK: Springer Nature Limited.

National Action Plan for Energy Efficiency (2008). National Action Plan for Energy Efficiency Vision for 2025: A Framework for Change. Retrieved from https://www.epa.gov/sites/production/files/2015-08/documents/vision.pdf

Meneses-Viveros, A., Hernández-Rubio, E., Mendoza, S., Rodríguez, J., \& Márquez Quintos, A.B. (2018). Energy saving strategies in the design of mobile device applications. Sustainable Computing: Informatics and Systems, 19, 86-95. https://doi.org/10.1016/j.suscom.2018.07.011

Pająk, K., Kvilinskyi, O., Fasiecka, O., \& Miśkiewicz, R. (2017). Energy security in regional policy in Wielkopolska region of Poland. Economics and Environment, 2(61), 122-138. Retrieved from https://www.ekonomiaisrodowisko.pl/uploads/eis\%2061/11_pajak.pdf

Peiser, R.B., \& Frej, A.B. (2003). Professional Real Estate Development: The ULI Guide to the Business. Second Edition. Washington, D.C.: ULI the Urban Land Institute. 
Thøgersen, J. (2018). Frugal or green? Basic drivers of energy saving in European households. Journal of Cleaner Production, 197, Part 1, 1521-1530. https://doi.org/10.1016/j.jclepro.2018.06.282

Zhang, C.-Y., Yu, B., Wang, J.-W., \& Wei, Y-M. (2018). Impact factors of household energy-saving behavior: An empirical study of Shandong Province in China. Journal of Cleaner Production, 1851, 285-298. https://doi.org/10.1016/j.jclepro.2018.02.303 